University of Nebraska - Lincoln

DigitalCommons@University of Nebraska - Lincoln

$8-9-2008$

\title{
Relating groundwater to seasonal wetlands in southeastern Wisconsin, USA
}

John D. Skalbeck

University of Wisconsin-Parkside, skalbeck@uwp.edu

Donald M. Reed

Southeastern Wisconsin Regional Planning Commission, dreed@sewrpc.org

Randall J. Hunt

US Geological Survey - Wisconsin Water Science Center, rjhunt@usgs.gov

Jamie D. Lambert

Wisconsin Department of Natural Resources, jamie.lambert@wisconsin.gov

Follow this and additional works at: https://digitalcommons.unl.edu/usgsstaffpub

Part of the Earth Sciences Commons

Skalbeck, John D.; Reed, Donald M.; Hunt, Randall J.; and Lambert, Jamie D., "Relating groundwater to seasonal wetlands in southeastern Wisconsin, USA" (2008). USGS Staff -- Published Research. 84. https://digitalcommons.unl.edu/usgsstaffpub/84

This Article is brought to you for free and open access by the US Geological Survey at DigitalCommons@University of Nebraska - Lincoln. It has been accepted for inclusion in USGS Staff -- Published Research by an authorized administrator of DigitalCommons@University of Nebraska - Lincoln. 


\title{
Relating groundwater to seasonal wetlands in southeastern Wisconsin, USA
}

\author{
John D. Skalbeck • Donald M. Reed • Randall J. Hunt • \\ Jamie D. Lambert
}

\begin{abstract}
Historically, drier types of wetlands have been difficult to characterize and are not well researched. Nonetheless, they are considered to reflect the precipitation history with little, if any, regard for possible relation to groundwater. Two seasonal coastal wetland types (wet prairie, sedge meadow) were investigated during three growing seasons at three sites in the Lake Michigan Basin, Wisconsin, USA. The six seasonal wetlands were characterized using standard soil and vegetation techniques and groundwater measurements from the shallow and deep systems. They all met wetland hydrology criteria (e.g., water within $30 \mathrm{~cm}$ of land surface for $5 \%$ of the growing season) during the early portion of the growing season despite the lack of appreciable regional groundwater discharge into the wetland root zones. Although root-zone duration analyses did not fit a lognormal distribution previously noted in groundwater-dominated wetlands, they were able to discriminate between the plant communities and showed that wet prairie communities had shorter durations of continuous soil saturation than sedge meadow communities. These results demonstrate that the relative rates of groundwater outflows can be important
\end{abstract}

Received: 24 January 2008 / Accepted: 24 June 2008

Published online: 9 August 2008

(C) Springer-Verlag 2008

\author{
J. D. Skalbeck ( $\square)$ \\ Department of Geosciences, \\ University of Wisconsin-Parkside, \\ 900 Wood Road, Kenosha, WI 53141, USA \\ e-mail: skalbeck@uwp.edu
}

\section{M. Reed}

Southeastern Wisconsin Regional Planning Commission,

W239 N1812 Rockwood Drive, Waukesha, WI 53187-1607, USA e-mail: dreed@sewrpc.org

\section{R. J. Hunt}

US Geological Survey - Wisconsin Water Science Center, 8505 Research Way, Middleton, WI 53562, USA

e-mail: rjhunt@usgs.gov

\section{J. D. Lambert}

Wisconsin Department of Natural Resources,

141 NW Barstow Street, Room 180, Waukesha, WI 53188, USA e-mail: jamie.lambert@wisconsin.gov for wetland hydrology and resulting wetland type. Thus, regional stresses to the shallow groundwater system such as pumping or low Great Lake levels can be expected to affect even drier wetland types.

Keywords Groundwater/surface-water relations . Groundwater monitoring · General hydrogeology

\section{Introduction}

Wetland issues have become increasingly prominent as the effects of large-scale wetland losses are assessed. It has been estimated that $53 \%$ of the wetlands of the conterminous United States have been lost since European settlement began in the 1700s (Mitsch and Gosselink 2000). The effects of wetland losses and recognition of their societal value has led to the adoption of laws that attempt to protect wetlands (National Cooperative Highway Research Program 1996). In some states within the Great Lakes Basin, the estimated wetland losses can be as high as 80 to $90 \%$ (Mitsch and Gosselink 2000). In recognition of the importance of this loss, appropriate identification, delineation, and management of remaining wetlands within the United States are needed to assess the effectiveness of wetland protection plans. However, our understanding of the fundamental components of wetlands (i.e., hydrology, soils, vegetation, and topography), and their interaction with each other, is often not sufficient to meet this goal (Hunt 1996; Hunt et al. 1998, 1999), especially for wetlands that are only seasonally wet.

Hydrology is recognized as a primary influence on wetland development (Carter 1986; Erwin 1989; Mitsch and Gosselink 2000). Understanding hydrology is critical for quantifying wetland functions and processes (Good et al. 1978; Greeson et al. 1979; and Ivanov 1981; Hunt et al. 1997). The scientific literature associated with inland freshwater wetlands (the type most prevalent in Great Lakes coastal zone) is less extensive than other wetland types in the United States such as salt marsh wetland systems. Moreover, at certain times of the growing season, drier members of this category (i.e. wet prairies and sedge meadows) may be difficult to identify and delineate as wetlands. Indeed, these drier/seasonal wetlands are specifically singled out as wetland types deserving special 
consideration in the 1987 Corps of Engineers Wetland Delineation Manual (USACE 1987). Due to the relatively easy access during dry times of the year, many of these wetland types are converted to non-wetland related uses. As a result, areally extensive examples of these drier wetland types have become rare, both within and outside of the Great Lakes Basin. As a result of these factors, a substantial body of previous work does not exist and our understanding has primarily been restricted to extrapolation from other ecosystems or wetland types.

From a regulatory perspective, identification and delineation of these "seasonal" wetlands that are dry during much of the growing season is hampered by the accepted practice of short term assessments based upon one or two relatively brief site visits (often conducted during dry periods of the growing season) and by the difficulty in identifying wetland hydrologic indicators during dry conditions. Indeed, it is not uncommon for shallow water table wells used to characterize wetland hydrology to go dry during the middle and late growing season. Further, groundwater-fed wetlands often receive a portion of their source water from the watershed outside the wetland boundary delineation line; therefore, an understanding of the contributing sources of water to the wetland community is needed to truly protect the wetland system. Occasional site visits during dry periods of the growing season may make it difficult to elucidate these wetland-watershed connections. Moreover, areas in the Great Lakes Basin that have the appropriate climate conditions for these drier seasonal wetland systems (more southern Great Lakes watersheds) are among the most heavily developed areas of the basin. Increased knowledge of these communities will help in assessing the effects of the wetland loss and will help identify the areas important for preserving the remnant communities.

The objective of this study is to characterize two seasonal wetland types (wet prairie and sedge meadows, USACE 1987), and relate how a longer-term, more encompassing, characterization of the hydrology relates to the more time-integrated measures of soil and plant properties. In addition to standard wetland delineation metrics, detailed groundwater measurements were used to elucidate the interaction of groundwater with the wetlands, and evaluate how standard water-table metrics used in wetter conditions perform for drier wetland types. This combination of standard and more sophisticated methods allows evaluation of relations between the wetland characteristics and: (1) sources of water and landscape position; and (2) common statistics for reporting wetland hydrology. Results from this study are transferable to similar drier freshwater wetlands in and out of the coastal zone.

\section{Site description}

The study area is located along Lake Michigan in southeastern Kenosha County, Wisconsin (WI), within the Carol Beach/Chiwaukee Prairie area of the village of
Pleasant Prairie (Fig. 1). This area is an approximately 740-ha beach ridge and swale complex consisting of beach dune, oak savanna, dry to wet prairie, southern sedge meadow, shallow marsh, calcareous and prairie fens, and shrub carr, with minor stands of lowland hardwoods. The surface soils are largely composed of the Granby fine sandy loams and the Boyer loamy sands (Link and Demo 1970). Single-family residential and related land uses occupy nearly all of the oak savanna, most of the fore-dune area, and the beach ridges in selected portions of the study area. The study area lies entirely within the Great Lakes Basin, with tributary creeks (Barnes Creek and Tobin Creek) discharging directly to Lake Michigan. The surface water subcontinental divide is approximately $5 \mathrm{~km}$ west of the study area, where surface water runoff discharges to the Des Plaines River and its tributaries.

\section{Geologic setting}

The presence of coastal wetlands within the study area is linked to the Zion beach-ridge plain, an elongated landform extending along Lake Michigan for nearly $29 \mathrm{~km}$ between Kenosha, Wisconsin, and North Chicago, Illinois (Chrzastowski 2001). Beach-ridge plains are composed of linear ridges of mostly coarse-grained sediment deposited by storm waves along the upper part of the beach and are laterally continuous for great distances along the shore. The ridges provide an approximation of former shorelines. As the lake level fluctuates, new ridges form approximately parallel to earlier sets enclosing low-lying swales where organic-rich and more fine-grained material accumulates, creating possible sites for wetlands. The beach-ridge plain "washboard" topography is most pronounced south of Zion, Illinois, and is more subtle in the study area where elevation differences between ridge and swale are generally less than $1 \mathrm{~m}$. The northern extent of the Zion beach-ridge plain deposits is approximately coincident with the northern portion of the study area. Well logs from this study indicate that deposits in the northern portion of the study area (location 3) are less sandy than the southern area (location 1). Formation of the Zion beach-ridge plain began around 5,500 BP during the Nipissing Phase of Proglacial Lake Chicago (Chrzastowski 2001).

The beach-ridge plain is generally about $0.8 \mathrm{~km}$ wide in the study area and is bounded to the west by N-S trending bluffs consisting of clayey till of the Lake Border Moraine (Schneider 1983) that marks the farthest inland advance of Lake Michigan. The Chicago and North Western railroad line follows the crest of the bluff (Fig. 1). West of the bluff the topography assumes the hummocky relief typical of glacial moraine deposits. State of Wisconsin Department of Natural Resource well logs indicate the tills are approximately $15 \mathrm{~m}$ thick and underlain by Silurian dolomite. The beach deposits and moraine deposits constitute an unconfined aquifer in which groundwater flow is controlled largely by the stage of surface water features. Regional groundwater flows 


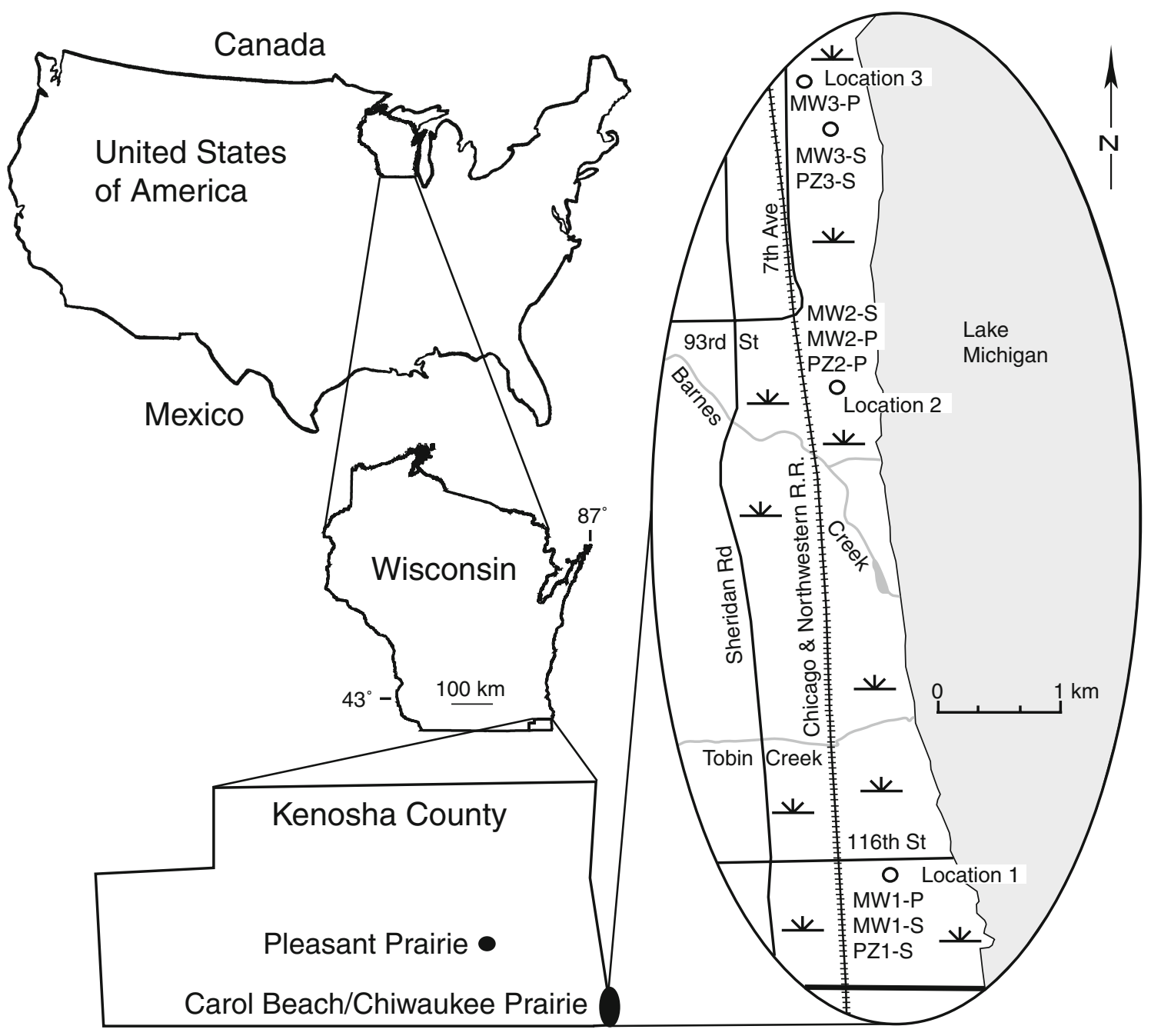

Zion, Illinois

Fig. 1 Schematic site map showing the three study locations. General locations are indicated for the water-table wells $(M W 1-S, M W 1-P$, $M W 2-S, M W 2-P, M W 3-S, M W 3-P)$ and deep piezometers $(P Z 1-S, P Z 2-P, P Z 3-S)$ where $S$ indicates sedge meadow site and $P$ indicates wet prairie site

from the upland moraine areas toward Lake Michigan and toward creeks that occupy V-shaped ravines incised into the glacial sediments. These ravines were likely cut $10,000-5,500$ years ago when lake levels were around $100 \mathrm{~m}$ lower than today (Chrzastowski 2001).

Annual precipitation within the study area averages approximately $110 \mathrm{~cm}$ annually based on the 1971-2000 Climate Analysis for Wetlands (WETS) data for Kenosha, WI (NRCS 2007). Most of the precipitation on the moraine is returned to the atmosphere by evapotranspiration or, secondarily, becomes surface runoff to local streams. Studies in southeastern Wisconsin suggest that only $10 \%$ or less of precipitation infiltrates to the water table in areas of clay-rich till along Lake Michigan (Cherkauer 2004); however, a higher percentage infiltrates in sandy areas such as beach-ridge plains (SEWRPC 2004).

\section{Precipitation and lake level}

Because the study wetlands are dependent on precipitation and are part of a groundwater system that is connected to adjacent Lake Michigan, these factors were considered in the analysis. The results from this study document coastal wetland conditions during the drier than normal 2003 and 2005 growing seasons and the wetter than normal 2004 growing season. Precipitation conditions were evaluated by comparing local data during the 2003-2005 study period with historical data recorded from 1971-2000 (Fig. 2) using a standard WETS analysis (NRCS 1995). Local data are from the City of Kenosha Southport Park Wastewater Treatment Plant, which is located approximately $0.5 \mathrm{~km}$ north of location 3 (Fig. 1). Monthly precipitation was evaluated using the 30th and 70th percentiles obtained from the WETS table for Kenosha (station WI4174) available from the US Department of 

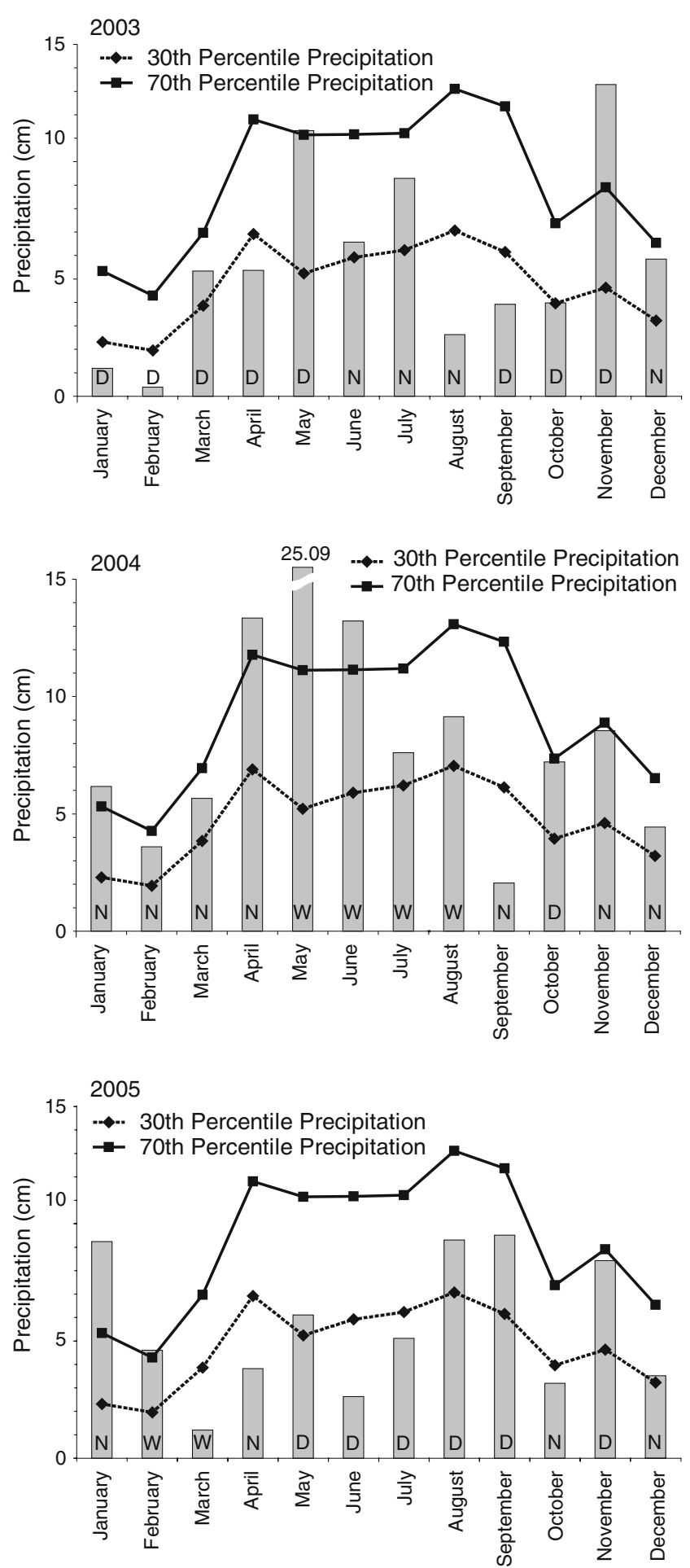

Fig. 2 Summary of WETS analysis for the study period. Bars indicate monthly precipitation from the City of Kenosha Southport Park wastewater treatment plant. Points and lines represent the 30th and 70th percentile precipitation from the USDA National Water and Climate Center WETS table. $D, N$, and $W$ denote dry, normal, and wet conditions, respectively, based on a WETS weighted score from the previous 3-month period of precipitation, with the most recent month weighted the greatest
Agriculture (USDA) National Water and Climate Center (NRCS 2007). The WETS table provides monthly thresholds for below normal (lowest 3 years in 10) and above normal (highest 3 years in 10). Each month was rated (dry, normal, wet) based on a weighted 3-month period of antecedent precipitation with the most recent month weighted the greatest.

Below average precipitation during the study period is thought to be a factor in the historically low lake levels recorded for Lake Michigan/Huron (Fig. 3). Compared with lake levels recorded from 1918 through 2005, the monthly average lake levels from 2002 through 2005 are between 8 and $15 \mathrm{~cm}$ below the long-term average. Lake levels during the 2003 growing season are only $6-9 \mathrm{~cm}$ above the historical record lows. A sustained period with lake levels this low was last observed in the mid-1960s.

\section{Methods}

The six wetland sites were characterized using standard wetland delineation techniques and protocols described in the regulatory manual and guidance for the United States (USACE 1987). The sites were sampled for vegetation on three occasions (28 July 2003; 8 October 2003; 17 and 25 June 2004) during the growing season to record plant species and their percent-cover values. Each site was sampled randomly by estimating percent cover within three $1-\mathrm{m}^{2}$ quadrats. Thus, a total of 18 quadrats ( 9 wet prairie and 9 sedge meadow quadrats) were sampled. At each site, corner points were established $5 \mathrm{~m}$ directly north, east, and south of each well. For the north and east quadrats, the corner point was considered to be the southwest corner of a $1-\mathrm{m}^{2}$ quadrat. At the south quadrat, the corner point was considered to be the northwest corner. At each sample point, meter sticks aligned in the cardinal directions were used to layout the quadrat. If the resulting quadrat fell outside of the desired vegetation type, the length and/or the direction to the quadrat was modified accordingly. Cover values were recorded for all vascular plants to the species level within each quadrat on the three sampling occasions. Threatened and endangered species were also noted. For those plants unidentified in the field, specimens were collected for later identification in the laboratory. On each date, percent cover for each species in each plant community type at each well was calculated as the average cover for the three quadrats. The final percent cover was the mean of the three seasonal values. Tabular summaries of the species composition of each site were prepared and sites were analyzed by the Bray-Curtis ordination (Bray and Curtis 1957) using PC-ORD software package (McCune and Meford 1995). Two sites are chosen as endpoints for each axis and all the other sites are ordinated relative to these endpoints, based upon their species composition and cover value similarities. So, the more similar stands will group closer together. In addition, the hydrophytic indicator status was applied to each species recorded.

Soil samples were collected randomly at each of the six sites on 23 June 2004, and characterized with the assistance 


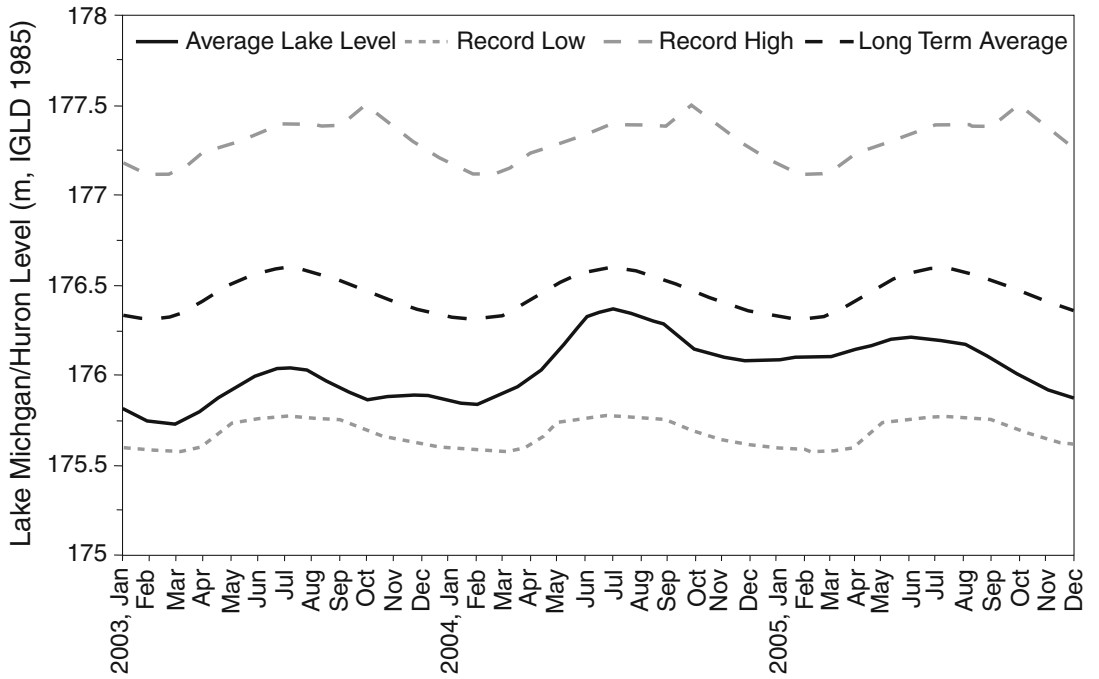

Fig. 3 Average monthly lake levels for Lake Michigan/Huron during the 3 years of the study along with the long term monthly average and monthly record low and high. IGLD 1985 is the International Great Lakes Datum 1985 revision prepared from data collected between from 1982 to 1988

of a soil scientist from the USDA, Natural Resources Conservation Service (NRCS). Soil samples were collected using a narrow spade to depths of $63 \mathrm{~cm}$ below soil surface. Soil texture class, Munsell color (MacBeth Division of Kollmorgen Instruments Corporation 2000), and thickness were documented for each soil horizon. Field indicators of hydric soils were identified based on the NRCS national list of field indicators (NRCS 2007).

Given the emphasis on wetland hydrology in this work, hydrologic characterization performed at the sites was more extensive than is typical for wetland delineation. Six water-table wells (designated MW) and three deeper piezometers (designated PZ) were installed at three locations in the study area (Fig. 1) between 23 and 25 April 2003 by means of hydraulic push equipment. A water-table well (long screen intersecting the uppermost groundwater) was installed at each of the six plant community sites - sedge $(\mathrm{S})$ and prairie $(\mathrm{P})$ sites at the three locations. A piezometer (short screen well completed below the water table) was installed at one site in each location within $3 \mathrm{~m}$ of the water-table well (Table 1). Wells and piezometers consist of $2.54 \mathrm{~cm}$ diameter PVC riser/casing and stainless steel screen. Figure 4 shows the geologic $\operatorname{logs}$ from cores collected during well and piezometer installation along with the screen intervals at each location. Well and piezometer locations and tops of casing and land surface elevations were determined using GPS survey equipment.

The growing season has been defined as the portion of year when soil temperatures at $50 \mathrm{~cm}$ below the soil surface are higher than biological zero $\left(5^{\circ} \mathrm{C}\right.$; US Department of Agriculture 1985). This can be approximated by the number of frost-free days based on average temperatures from 5 of 10 years (US Department of Interior 1970). The growing seasons of 2003 and 2004 for eastern Kenosha County are from 14 April to 2 November (202 days). The first 10 days of the 2003 growing season were not recorded because measurement of water levels started on 24 April 2003; however, water levels for the entire 2004 and 2005 growing seasons were recorded.

Water level measurements were made in the six watertable wells and three piezometers from 24 April 2003, to 3 November 2005. Each water-table well was equipped with an unvented pressure transducer and integrated data logger

Table 1 Well and piezometer installation details

\begin{tabular}{lllllll}
\hline $\begin{array}{l}\text { Well/piezometer } \\
\text { identification }\end{array}$ & $\begin{array}{l}\text { Riser height } \\
\text { above grade }(\mathrm{m})\end{array}$ & $\begin{array}{l}\text { Total well } \\
\text { length }(\mathrm{m})\end{array}$ & $\begin{array}{l}\text { Top of casing } \\
\text { elevation }(\mathrm{m} \text { amsl) }\end{array}$ & $\begin{array}{l}\text { Land surface } \\
\text { elevation }(\mathrm{m} \text { amsl) }\end{array}$ & $\begin{array}{l}\text { Pressure transducer } \\
\text { sensor depth }(\mathrm{m} \text { bg) }\end{array}$ & $\begin{array}{l}\text { Well bottom } \\
\text { depth }(\mathrm{m} \text { bg) }\end{array}$ \\
\hline MW1-S & 0.77 & 1.90 & 180.04 & 179.27 & 0.95 & 1.13 \\
MW1-P & 0.81 & 1.89 & 179.84 & 179.03 & 1.00 & NA \\
PZ1-S & 0.88 & 4.37 & 180.12 & 179.24 & 0.92 & 1.08 \\
MW2-S & 0.85 & 1.92 & 181.25 & 180.40 & 1.01 & 1.07 \\
MW2-P & 0.77 & 1.93 & 181.53 & 180.76 & 0.85 & 2.61 \\
PZ2-P & 0.70 & 3.31 & 181.48 & 180.78 & 1.15 & 1.22 \\
MW3-S & 0.74 & 1.65 & 181.73 & 180.99 & NA & 3.55 \\
MW3-P & 0.75 & 1.97 & 181.64 & 180.77 & & \\
PZ3-S & 0.87 & 4.42 & 181.64 & &
\end{tabular}

Notes

$m$ meters; $m$ amsl meters above mean sea level (North American datum of 1929); $m$ bg meters below grade; $N A$ not applicable, no transducer installed, water levels measured manually 


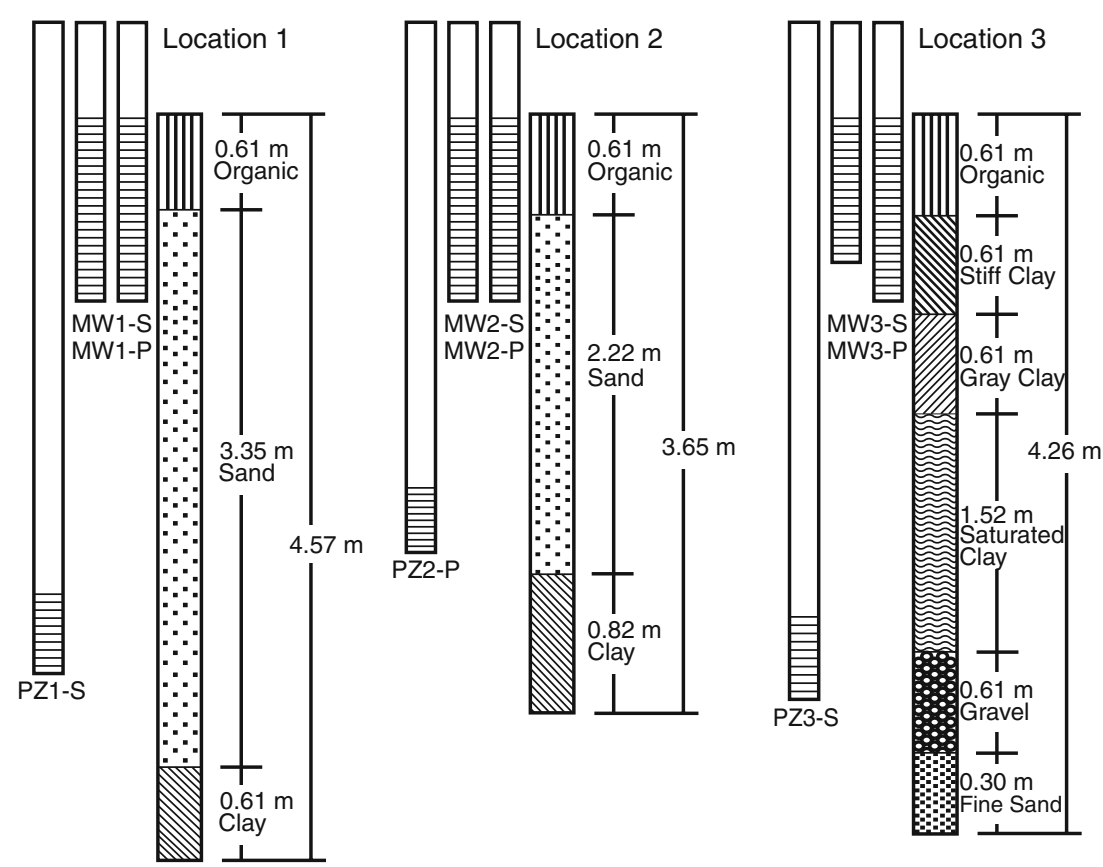

Note: Land surface elevations normalized to common surface plane.

Fig. 4 Schematic cross-sectional representation of the water-table well and deep piezometer screen intervals and depths along with the geologic logs from soil cores obtained during installation

that recorded water pressure and temperature at 30-min intervals. When using unvented pressure transducers, the total water pressure measured in each well represents the sum of the barometric pressure and pressure from the height of water above the pressure transducer sensor. Thus, a barometric pressure transducer was installed above the water table in the casing of well MW2-P to correct the unvented pressure transducer data for barometric pressure fluctuations and was set to record barometric pressure and air temperature at 30-min intervals. Water elevation in each well was calculated to the nearest $0.3 \mathrm{~cm}$ by subtracting the barometric pressure from the total water pressure and adding the resulting height of water above the sensor to the sensor depth; depth to water was calculated by subtracting the water elevation from the ground surface elevation at each well (see Table 1). Hand measurements of depth to water were collected approximately weekly and recorded to $0.3 \mathrm{~cm}$ from water-table wells and piezometers during the growing season using an electronic sounder and/or steel tape. During the non-growing season, depth-to-water measurements were collected approximately monthly. Depth-to-water below grade (land surface) was calculated by subtracting the difference between the top-of-casing and land surface elevations (same as riser height above grade) from the depth-to-water measurement.

Periods of continuous root zone residence times were determined for each of the six water-table wells and each growing season using the method of Hunt et al. (1999); for clarity the standard normal deviate has been converted to cumulative probability for plotting. Continuous lognormal distributions were fit to the residence time data. The 7- and 10-day high water level average statistics of Henszey et al. (2004) were calculated for each water-table well and each growing season to provide another comparison between sites. A simple moving average was used, of the individual water levels for the previous number $(n-1)$ of days rather than averaging the mean daily water level.

\section{Results and discussion}

\section{Vegetation results}

A total of 66 species were recorded at the 3 wet prairie sites and 74 species were documented at the 3 sedge meadow sites. The percent cover results and hydrophytic indicator status for each of the species at these six sites are provided in a report by the Southeastern Wisconsin Regional Planning Commission (SEWRPC 2004). The major dominant plant species and associated percent cover for each wetland site (Table 2) were determined using the 50/20 rule (USACE 1987). Eight species were determined to be major dominants at the three wet prairie and the three sedge meadow sites. Each of these species, with the exceptions of Andropogon gerardii (FAC-, see Table 2 notes) at wet prairie site 1 and sedge meadow site 1 , and Potentilla simplex (FACU-) at sedge meadow site 3 , is considered a hydrophyte. Subsequently, these six seasonal wetlands were dominated by hydrophytic vegetation based upon percent cover values and each site exhibited a positive FAC-neutral test, which may be used as a secondary hydrologic indicator.

The results of a Bray-Curtis ordination of the 18 sample site quadrats (Fig. 5) show that the sedge meadow quadrats cluster together fairly well because of their similar vegetative composition with higher percent cover 


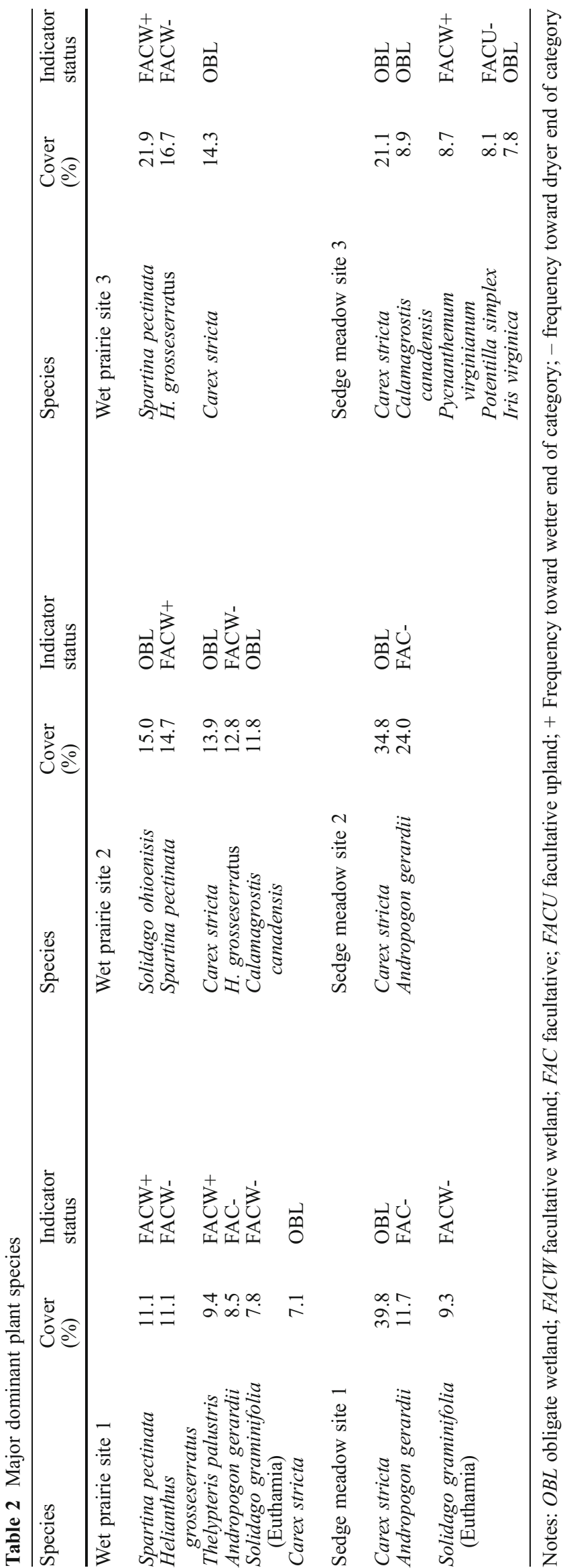

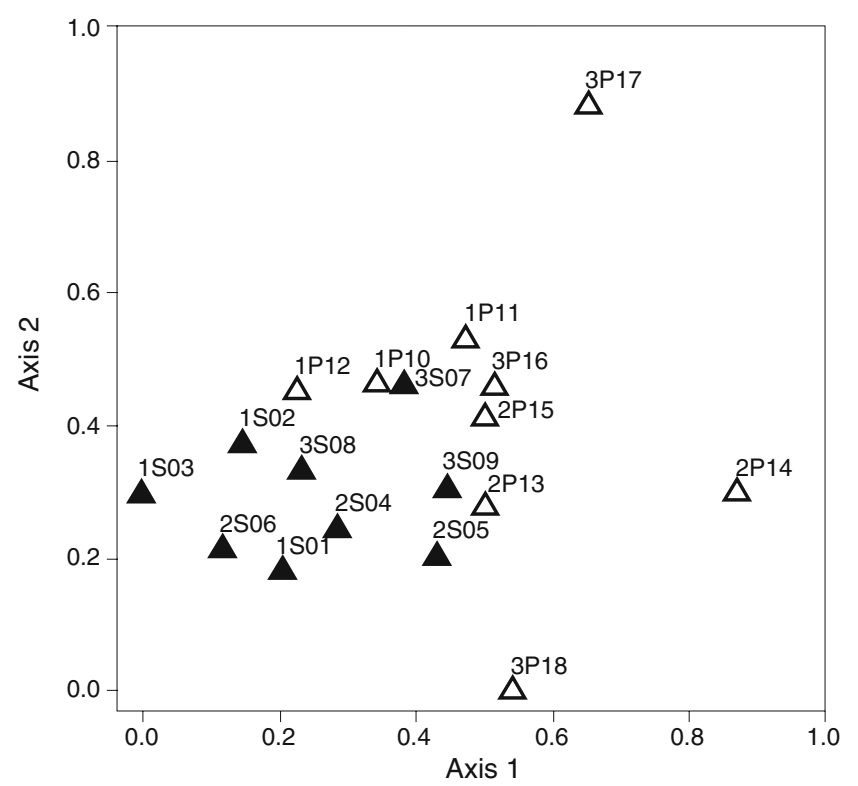

Fig. 5 Plot showing results of Bray-Curtis ordination of the 18 sample quadrats sampled for vegetative cover. The first two label digits indicate the sedge meadow sites $(1 S, 2 S, 3 S)$ and wet prairie sites $(1 P, 2 P, 3 P)$ and the last two digits represent sequential quadrat number

values for certain major dominant species (e.g., Carex stricta) and slightly higher species richness. The ordination of the wet prairie quadrats shows a much more scattered and variable pattern due to their lower and more variable percent cover values for the major dominant species. Wet prairie site 1 shows the least scatter and plots closest to the sedge meadow quadrats. In contrast, Wet prairie site 3 exhibits the greatest variability and plots furthest from the sedge meadow quadrats. These results are consistent with a hydrologic driver. Sites with wetter conditions (left half of axis 1) favor more homogeneity in major dominant plant species (e.g., the predominance of Carex stricta in sedge meadow sites) because there is a smaller number of possible dominant species able to tolerate longer periods of inundation and saturation on these sites. Less homogeneity in major dominant plant species (larger scatter in Fig. 5) was observed in the wet prairie sites because there are a larger number of possible plant species available to compete for dominance when the period of inundation and saturation is reduced (right half of axis 1).

\section{Soil results}

Hydric soil indicators were identified in accordance with the NRCS list of hydric soil field indicators (NRCS 2006) at each of the three sedge meadow sites and the three wet prairie sites (Table 3). The four most common indicators observed are surface accumulations of organic matter (A10: $2 \mathrm{~cm}$ muck) found in sedge meadow site $2 \mathrm{~S}$ and wet prairie sites $1 \mathrm{P}$ and $2 \mathrm{P}$; histic epipedons (A2) found in sedge meadow site $1 \mathrm{~S}$ and wet prairie site $1 \mathrm{P}$; stratified layers (A5) found in sedge meadow sites $1 \mathrm{~S}$ and $2 \mathrm{~S}$; and 
Table 3 Summary of soil profiles and hydric indicators

\begin{tabular}{|c|c|c|c|c|c|}
\hline Site & Depth $(\mathrm{cm})$ & Texture & Munsell color & Other features & Hydric indicator \\
\hline $1 \mathrm{P}$ & $\begin{array}{l}0-15 \\
15-63\end{array}$ & Sapric muck w/ stripped sand & $\begin{array}{l}\mathrm{N} 2.5 / 0 \\
10 Y \mathrm{R} 5 / 3\end{array}$ & Redox masses (7 5YR 4/6) & $\mathrm{A} 2, \mathrm{~A} 10, \mathrm{~S} 1, \mathrm{~A} 16$ \\
\hline $1 \mathrm{~S}$ & $\begin{array}{l}0-20 \\
20-31 \\
31-41 \\
41-63\end{array}$ & $\begin{array}{l}\text { Sapric muck w/ } 2 \% \text { sand } \\
\text { Sapric muck w/ } 3 \mathrm{~mm} \text { strata sand } \\
\text { Sand w/ } 3-18 \mathrm{~mm} \text { strata muck } \\
\text { Sand w/ } 3 \mathrm{~mm} \text { strata muck }\end{array}$ & $\begin{array}{l}\text { N } 2.5 / 0 \\
\text { N } 2.5 / 0 \\
\text { 10YR } 4 / 2 \\
\text { 10YR } 4 / 2\end{array}$ & $\begin{array}{l}\text { Sand }(10 \mathrm{YR} 5 / 2) \\
\text { Redox masses }(7.5 \mathrm{YR} 4 / 6) \\
\text { Redox masses }(7.5 \mathrm{YR} 4 / 6)\end{array}$ & $\mathrm{A} 2, \mathrm{~A} 5$ \\
\hline $2 \mathrm{P}$ & $\begin{array}{l}0-13 \\
13-15 \\
15-26 \\
26-63\end{array}$ & $\begin{array}{l}\text { Silt loam } \\
\text { Silt loam w/ stripped sand } \\
\text { Fine sandy loam } \\
\text { Loamy fine sand }\end{array}$ & $\begin{array}{l}\text { 10YR } 2 / 1 \\
\text { N } 2.5 / 0 \\
10 \text { YR } 4 / 2 \\
10 \text { YR } 4 / 3\end{array}$ & $\begin{array}{l}\text { Redox masses }(7.5 \mathrm{YR} 4 / 6) \\
\text { Redox masses }(7.5 \mathrm{YR} 4 / 6)\end{array}$ & A10 \\
\hline $2 \mathrm{~S}$ & $\begin{array}{l}0-5 \\
5-16 \\
16-37 \\
37-63\end{array}$ & $\begin{array}{l}\text { Sapric muck/mucky sand } \\
\text { Sapric muck w/ } 3 \mathrm{~mm} \text { strata sand } \\
50 \% \text { stratified Sapric Muck } \\
50 \% \text { sand } \\
\text { Fine sand } \mathrm{w} / 3-6 \mathrm{~mm} \text { strata muck }\end{array}$ & $\begin{array}{l}\text { N } 2.5 / 0 \\
\text { N } 2.5 / 0 \\
\text { N } 2.5 / 0 \\
10 \text { YR } 5 / 2 \\
10 \text { YR } 4 / 2\end{array}$ & $\begin{array}{l}\text { Sand (10YR 4/2) } \\
\text { Redox masses (7.5YR 4/6) }\end{array}$ & $\mathrm{A} 5, \mathrm{~A} 10$ \\
\hline $3 \mathrm{P}$ & $\begin{array}{l}0-28 \\
28-63\end{array}$ & $\begin{array}{l}\text { Silt loam } \\
\text { Loam }\end{array}$ & $\begin{array}{l}\text { 10YR 2/1 } \\
10 \mathrm{YR} 3 / 1\end{array}$ & & A4, A11 \\
\hline $3 \mathrm{~S}$ & $\begin{array}{l}0-23 \\
23-63\end{array}$ & $\begin{array}{l}\text { Mucky fine sand } \\
\text { Fine sand }\end{array}$ & $\begin{array}{l}\text { N 2.5/0 } \\
10 \text { YR 4/6 }\end{array}$ & & S1 \\
\hline
\end{tabular}

$A 2$ histic epipedon; $A 4$ hydrogen sulfide; $A 5$ stratified layers; $A 102 \mathrm{~cm}$ muck; $A 11$ depleted below dark surface; $A 16$ coastal prairie redox; S1 sandy mucky mineral

Note: The A16 indicator is currently being tested as a hydric soils indicator in the Great Lakes Basin

sandy mucky mineral (S1) found in sedge meadow site $3 \mathrm{~S}$ and wet prairie site $1 \mathrm{P}$. Wet prairie site $3 \mathrm{P}$ had the A4 (Hydrogen sulfide) and A11 (depleted below dark surface) indicators present during June 2004 when the site was inundated by approximately $10 \mathrm{~cm}$ of water. However, the A4 indicator usually disappears when the water level recedes and aerobic conditions develop in the soil column as the growing season progresses. Therefore, during the drier periods of the growing season, this site would be classified as containing a hydric soil based on the single A11 indicator. Other indicators observed within the study area include the distinct reduction oxidation concentrations (A16: coastal prairie redox, formerly called TS5: Chroma 3 sandy redox) found in wet prairie site 1P. Location 1 (sites $1 \mathrm{P}$ and $1 \mathrm{~S}$ ) and location 2 (sites $2 \mathrm{~S}$ and $2 \mathrm{P}$ ) exhibit the only consistent pattern of hydric soil indicators-the accumulations of organic matter in the surface layer (A2 and A10, respectively)-within the study area.

\section{Results of water level measurements}

Depths to water in the six water-table wells and three piezometers (Fig. 6) are shown along with daily precipitation, land surface (grade), and root zone $(30 \mathrm{~cm}$ below grade). Hand measurements from the water-table wells (not included in Fig. 6) show good agreement with data from sensors throughout the study period. The spiky pattern of water-level fluctuation for each of the six watertable wells suggests these wetland sites respond rapidly to precipitation input and evapotranspiration losses. Overall, the water levels measured indicate that during the latter portion (July through September) of the growing seasons, when the potentiometric surface is lowest, the water table is below the root zone at each of the six sites. This demonstrates potential problems for evaluating the required hydrologic criteria for wetland delineation at these locations if delineation visits were only conducted during the later part of the growing season.

The 2004 water levels are generally higher than 2003 water levels, corresponding to greater precipitation in that year. The 2005 water levels decline steadily during the growing season due to evapotranspiration losses and flow from the root zone to the deeper groundwater system not being offset by precipitation. Water levels from piezometers at locations 1 and 2 closely match with water levels in the water-table wells but do not show good agreement at location 3. This difference between the locations can be explained by assessing the local geologic conditions and their effect on groundwater flow. Similar subsurface lithologies occur at locations 1 and 2 with both exhibiting sand overlying clay (Fig. 4). The screen intervals indicate that the lower portions of water-table wells are within the same sand water-bearing zone as the piezometers. At location 3, the piezometer is screened in a thin gravel zone while the water-table wells are screened in stiff clay and locally separated from the piezometer screen by about 2 to $2.5 \mathrm{~m}$ of clay. The observed subsurface stratigraphy and disparate groundwater elevations suggest that the watertable wells and piezometer at location 3 measure two waterbearing zones that are not in good hydraulic continuity.

\section{Evaluating evapotranspiration effects on the water table}

Depths to water in the six water-table wells, normalized to the beginning water level measured in each time series, were analyzed over 2-day periods during the summer of 2003 (18-19 July), winter of 2004 (18-19 January), and summer of 2004 (17-18 July) to assess evapotranspiration effects on the dynamic response of the water table (Fig. 7). Values in parentheses indicate the actual depth to water at the beginning of the plot. Water levels decline significant- 

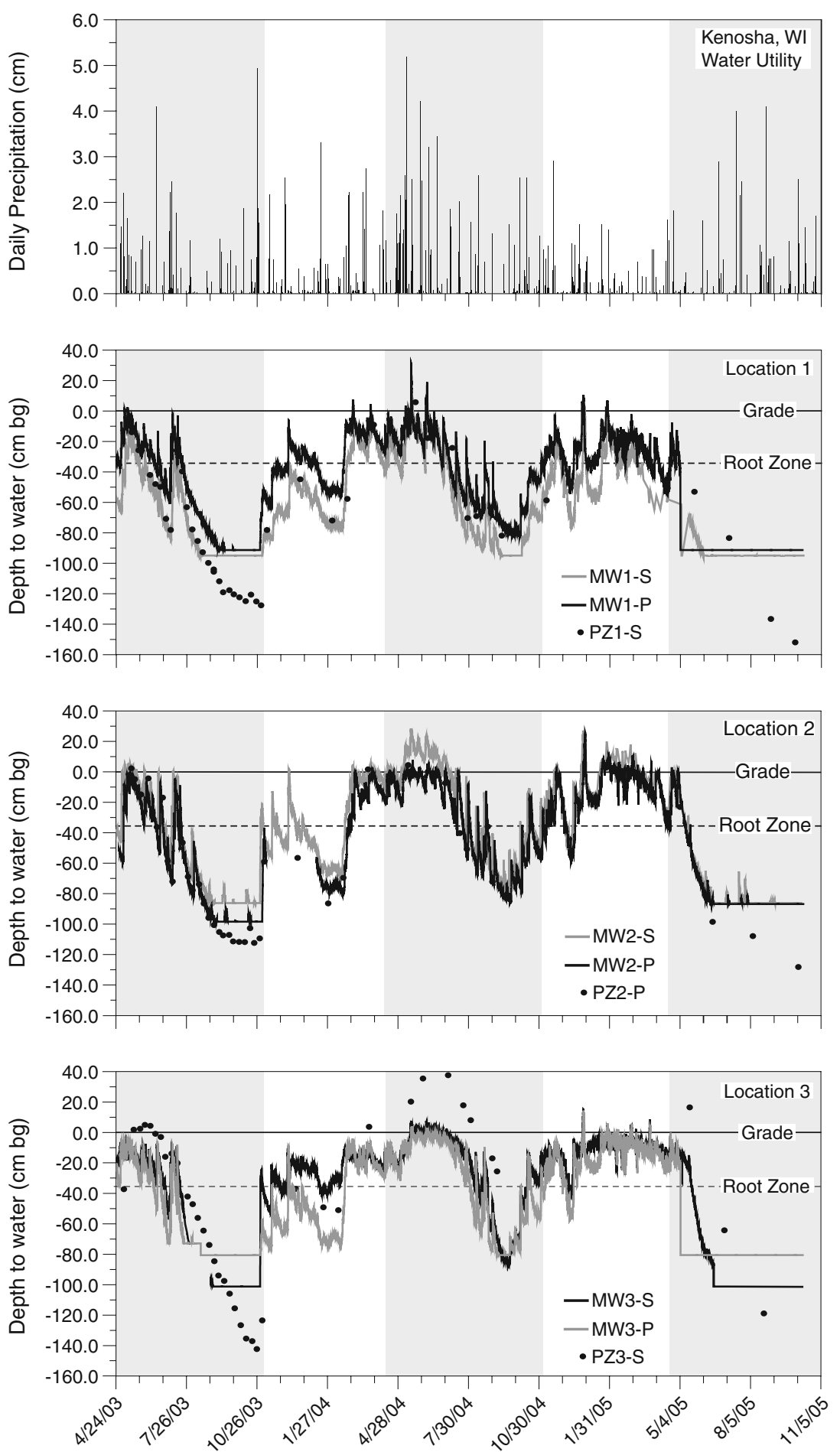

Fig. 6 Hydrographs of water-table wells and deep piezometers along with daily precipitation for the period April 2003 through October 2005. Growing seasons 2003, 2004, and 2005 indicated with shading

ly $(3-8 \mathrm{~cm})$ from sunrise to sunset on 18 and 19 July 2003 (Fig. 7a). The declining water levels are coincident with increasing air temperature, which is consistent with increases in the evapotranspiration rate. During the evenings of 18 and 19 July 2003, while air temperatures decline; however, water levels are characterized by a modest water level rebound. During the non-growing season, water levels do not change appreciably (Fig. 7b), with exception of a gradual increase (up to $3 \mathrm{~cm}$ in MW3S) that is likely in response to $0.56 \mathrm{~cm}$ of precipitation on 17 January 2004. The July 2003 declining pattern was also observed during July 2004 (Fig. 7c), but the water level decline $(1-10 \mathrm{~cm})$ is much less consistent between the six wells. The decline in water levels only during 
(a)

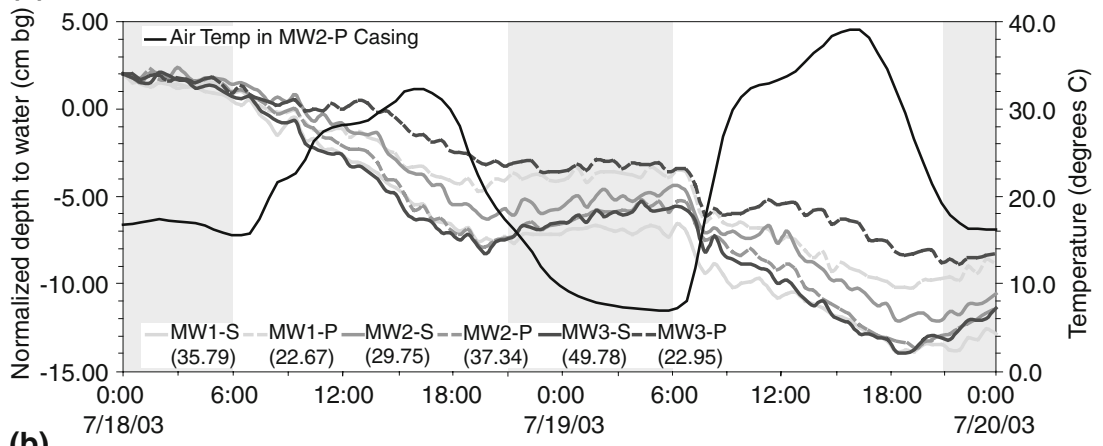

(b)

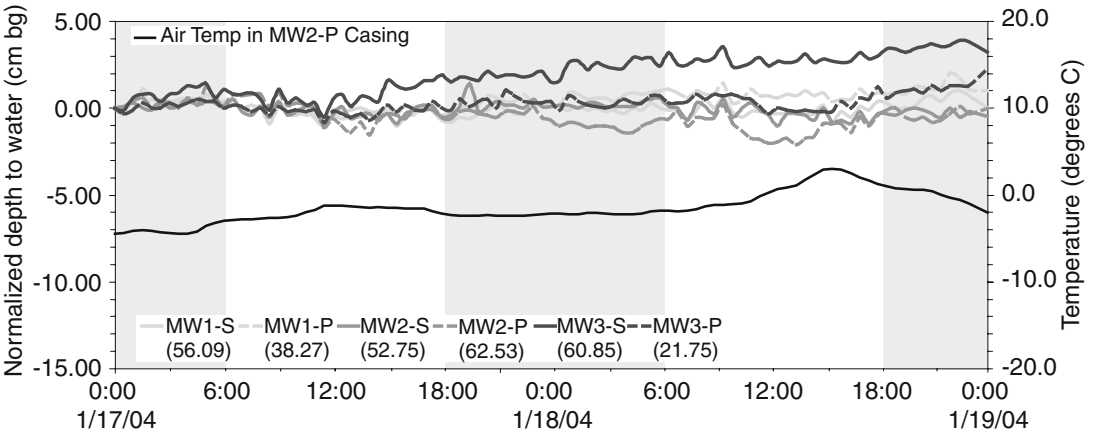

(c)

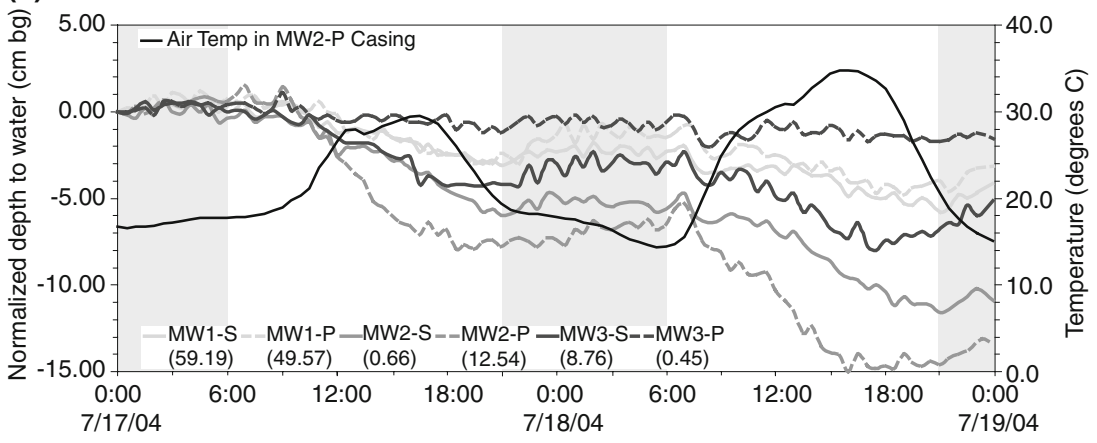

Fig. 7 Normalized hydrographs of water-table wells along with air temperature for selected 48-h periods to represent a summer 2003, b winter 2004, and c summer 2004. Values in parentheses indicate vertical adjustment of water depth to normalize hydrographs for evaluation of evapotranspiration. Non-daylight periods are indicated with shading

daylight hours (a diurnal effect) in both summer of 2003 and 2004 indicates that evapotranspiration is drawing down the water table in these wells. The modest water level rebound during the night periods shows that groundwater flow into the wetland is not a dominant source of water to these drier wetlands.

The relation of sedge meadow to wet-prairie drawdown was not consistent among the sites, and likely reflects the superposition of a similar evapotranspiration sink on the sitespecific rates of groundwater outflow due to local differences in aquifer properties between the sites. For example, local differences in hydraulic conductivity are likely limiting the groundwater outflow, and thus water level change, at MW3$\mathrm{P}$ (location 3 where the clayey substrate exists) compared to the other sites (Fig. 7). In addition, there may also be differences in the specific yield of the shallow wetland sediments at the sites, which would result in different water level changes for the same water loss. The relation of the 2003 response to the 2004 response appears to be related to air temperature. The maximum temperature difference between sunrise and sunset for the 2 days in July 2004 was much less $\left(9\right.$ and $\left.19^{\circ} \mathrm{C}\right)$ than for the 2 days in July $2003\left(16\right.$ and $32^{\circ} \mathrm{C}$ ), which likely accounts for the difference in water-table drawdown between these two growing season periods (Fig. 7).

\section{Root zone residence time and high water level characterizations}

Following the method described by Hunt et al. (1999), each well hydrograph was analyzed to determine the contiguous periods of time where the water level was at or above the root zone, defined as $30 \mathrm{~cm}$ below ground surface, during the growing seasons. This method incorporates the small-scale temporal fluctuations that can play a significant role in the wetland hydrology and is more consistent with the characteristic hydrologic thresholds presented by the National Research Council (1995). The resulting series of residence times (points), which represent a period of time that the water level was continually in the root zone, and a 
continuous lognormal distributions (lines) fit to the residence times for each of the six wetland sites are represented as cumulative probability plots (Fig. 8).

The misfits between the fitted lognormal distributions and the residence time data that are typical for this study are generally larger than that seen by Hunt et al. (1999). The authors attribute this larger misfit to the difference in dominant source of water to the wetland. Hunt et al. (1999) monitored sites that were primarily groundwaterdominated wetlands (Hunt et al. 1996) - conditions where lognormal distributions curves fit the residence time distributions much better. The drier wetland sites studied here, however, are primarily precipitation-dominated wetlands with little of the smoothing effects of continuous groundwater flow. Indeed, rather than a smoothing source of water, groundwater is serving as an additional sink of water from the root zone for these drier wetland types. It is likely that the lack of appreciable groundwater inflow, the presence of an additional groundwater sink at depth, an evapotranspi- ration sink near surface, along with the stochastic nature of climatic inputs, add sufficient variability to the signal such that it is more skewed than the lognormal distributions used in Hunt et al. (1999). This suggests additional distributions or summary statistics (such as those discussed below) might help generalize the goal of the Hunt et al. (1999) approach to drier wetland systems.

Because high-density, long-term water level data were available, an evaluation of one wetland hydrology criterion can be directly calculated. The longest durations of water levels in the root zone were observed in the early growing season, and demonstrate that each of these drier wetland sites meet the United States regulatory requirement of continuous soil saturation (measured water table within $30 \mathrm{~cm}$ of the land surface) during $5 \%$ of the growing season (approximately 10 days for 202-day growing season) according to the US Army Corps of Engineers Wetlands Delineation Manual (USACE 1987). The median duration periods calculated by the root zone
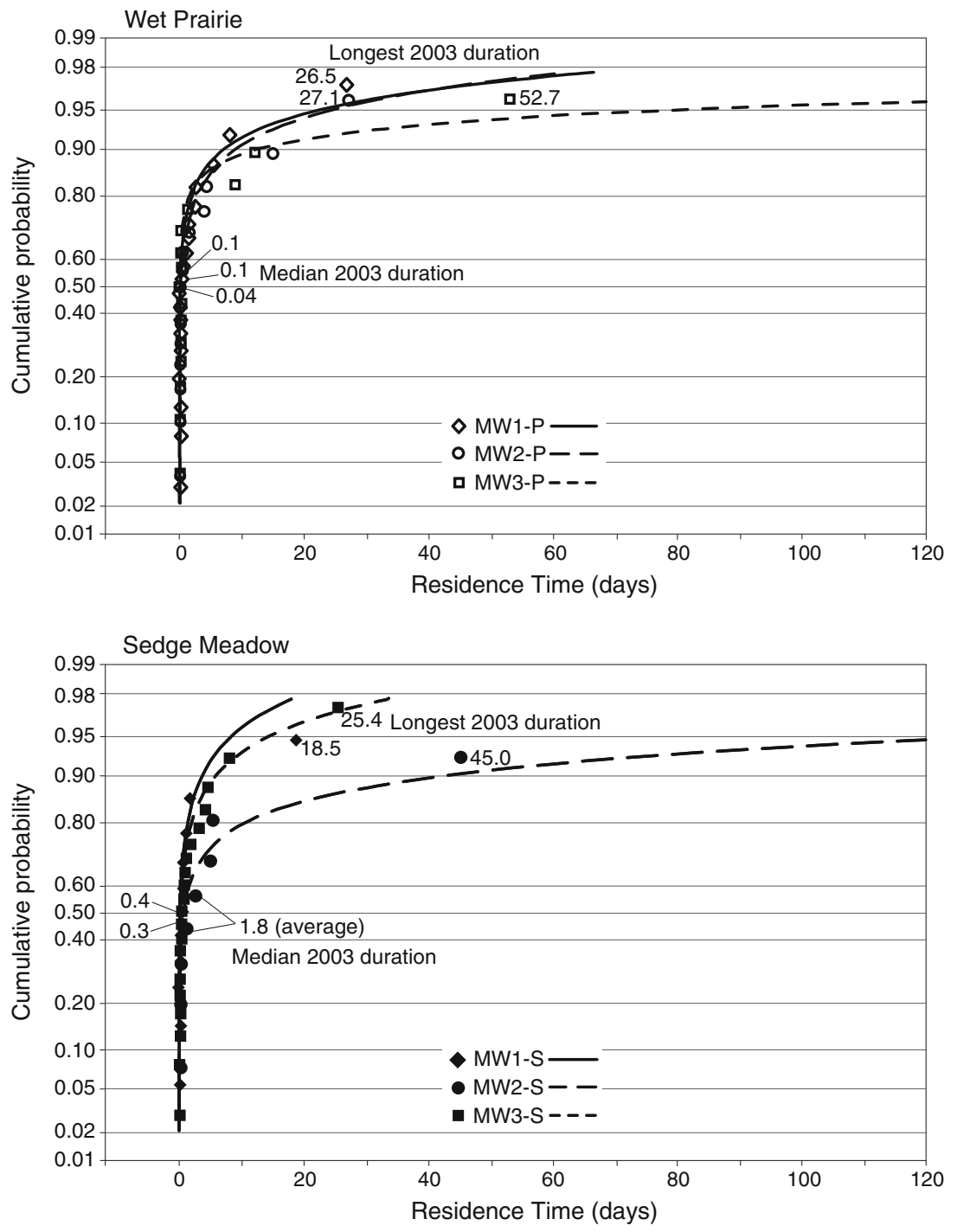

Fig. 8 Cumulative probability distribution of contiguous inundation for the 2003 growing season hydrographs. The plots show the residence time (points) and the corresponding lognormal distributions (lines) 
distributions provide an indication of the dominant length of inundation for each site, and had utility for discriminating between the sedge meadow and wet prairie plant communities. For each pair at the three locations, the wet prairie site consistently had a shorter median duration time $(0.1,0.1,0.04$ days) than the sedge meadow sites $(0.4$, 1.8, 0.3 days; Fig. 8). This finding is consistent with Reed (2002), who noted a similar difference in moisture gradient under the prairie-, calcareous-, and sedge-fen plant associations in southeastern Wisconsin. It is interesting to note that shorter duration high-water events (expressed by the median duration values shown in Fig. 8) appear to have an effect on the type of plant community in these drier wetlands; the longer duration high-water conditions that affect hydric/non-hydric soil development and hydrophytic/non-hydrophytic plant hydrologic criteria are commonly the regulatory metric of interest.

As an alternative to the relatively labor intensive rootzone residence curves, the water level data were also evaluated using two summary statistics that Henszey et al. (2004) identified as having utility for discriminating between plant communities in Nebraska: the 7- and 10day moving average high water level. In addition to general information about the magnitude of high-water levels, Henszey et al. (2004) noted that the $n$-day moving averages can be associated with a specific date. Thus, Table 4 provides a summary of the 7- and 10-day moving average high water levels calculated using the 30-min water level data, and the associated date. Moving averages could not be calculated in piezometers MW1-S and MW2-S for 2005 due to missing data resulting from equipment malfunction. The moving averages did not appear to separate the two plant communities at the Wisconsin study sites (Table 4), but did demonstrate that both wetland types had high water levels during early portions of the three growing seasons
(Table 4). Because $5 \%$ of the growing season is equal to 10 days in this area, the results of the 10-day moving average high water level suggest that each of the six sites meets the wetland hydrology criterion - even during the dry precipitation and low lake-level conditions of 2003 and 2005. This underscores the importance of site visits early in the growing season for observing wetland hydrology in these drier wetland types. However, the high water level cannot be used directly for wetland hydrology determinations without reporting the minimum water level during the same 10-day period because the current United States regulatory requirement is for continuous duration-a feature of the water level data that cannot be ascertained by the average high-water level statistic alone.

\section{Implications for seasonal wetland delination}

Although this study focused on a wetland system in the United States and its relation to the regulations therein, the fundamental issue of characterizing drier-type wetlands is not restricted to just the United States or regulatory requirements. Wetland structure and function are important on the landscape due to unique processes associated with their different plant communities, soil properties, and hydrologic regime. Thus, wetland delineations, which are important for identifying and protecting wetlands, are determined by plant community, soil, and wetland hydrology criteria. A notable difference between these three criteria is that plant communities and soil characteristics integrate the site conditions over a period of time, whereas wetland hydrology evaluations are a "snapshot" of the conditions at the time of the site visit. This snapshot may or may not be representative of the conditions that are reflected in the time-integrated plant and soil characterizations. The result of this disparity is that a

Table 4 Summary of 7-day and 10-day moving averages

\begin{tabular}{|c|c|c|c|c|c|}
\hline $\begin{array}{l}\text { Piezometer } \\
\text { identification }\end{array}$ & $\begin{array}{l}\text { Growing } \\
\text { season }\end{array}$ & $\begin{array}{l}\text { 7-day average high } \\
\text { water }(\mathrm{cm} \mathrm{bg})\end{array}$ & $\begin{array}{l}\text { 10-day average high } \\
\text { water }(\mathrm{cm} \mathrm{bg})\end{array}$ & $\begin{array}{l}\text { 7-day average high } \\
\text { water date }\end{array}$ & $\begin{array}{l}\text { 10-day average high } \\
\text { water date }\end{array}$ \\
\hline \multirow[t]{3}{*}{ MW1-P } & 2003 & -5.39 & -6.29 & $5 / 12 / 03$ & $5 / 25 / 03$ \\
\hline & 2004 & -1.26 & -3.35 & $5 / 25 / 04$ & $5 / 24 / 04$ \\
\hline & 2005 & -27.94 & -28.3 & $5 / 20 / 05$ & $5 / 21 / 05$ \\
\hline \multirow[t]{3}{*}{ MW1-S } & 2003 & -13.02 & -15.08 & $5 / 16 / 03$ & $5 / 24 / 03$ \\
\hline & 2004 & 2.39 & 0.91 & $5 / 25 / 04$ & $5 / 27 / 04$ \\
\hline & 2005 & NA & NA & NA & NA \\
\hline \multirow{3}{*}{ MW2-P } & 2003 & 2.38 & 1.78 & $5 / 16 / 03$ & $5 / 15 / 03$ \\
\hline & 2004 & 8.43 & 7.49 & $6 / 16 / 04$ & $6 / 18 / 04$ \\
\hline & 2005 & 2.83 & -0.03 & $6 / 16 / 05$ & $6 / 19 / 05$ \\
\hline \multirow[t]{3}{*}{ MW2-S } & 2003 & 6.14 & 5.73 & $5 / 16 / 03$ & $5 / 17 / 03$ \\
\hline & 2004 & 25.44 & 23.64 & $5 / 28 / 04$ & $5 / 28 / 04$ \\
\hline & 2005 & NA & NA & NA & NA \\
\hline \multirow[t]{3}{*}{ MW3-P } & 2003 & -5.42 & -5.89 & $5 / 11 / 03$ & $5 / 17 / 03$ \\
\hline & 2004 & 10.10 & 9.30 & $6 / 16 / 04$ & $6 / 18 / 04$ \\
\hline & 2005 & -2.22 & -3.13 & $4 / 14 / 05$ & $4 / 14 / 05$ \\
\hline \multirow{3}{*}{ MW3-S } & 2003 & -7.14 & -8.28 & $5 / 10 / 03$ & $5 / 15 / 03$ \\
\hline & 2004 & 2.16 & 1.32 & $6 / 16 / 04$ & $6 / 19 / 04$ \\
\hline & 2005 & -9.28 & -10.13 & $4 / 14 / 05$ & $4 / 14 / 05$ \\
\hline
\end{tabular}

Notes:

Positive high water values indicate water above grade

$N A$ not available; $c m$ bg centimeters below grade 
delineation performed in the middle or later growing season may find it difficult to identify obvious regulatory indicators of wetland hydrology (such as specified in USACE 1987), even though the plant communities and soils are consistent with wetland hydrology occurring at the site. This can be expected to typify seasonal wetlands that in most years have a period during the growing season in which they appear dry. In addition, the relation of the root zone to the larger groundwater system can be variable in space and time. Because groundwater outflows are controlled by the strength of the vertical gradient, regional declines in water table due to drought and low lake levels (SEWRPC 2004), or pumping, can be expected to manifest themselves in the wetland hydrology even if groundwater is not a dominant source of water to the wetland. Moreover, spatial and temporal variability suggest the need for insight into the deeper groundwater system in addition to the shallow root zone water levels commonly collected. This is especially true in the drier wetland types. Unlike the more spatially homogeneous groundwater inflow-dominated wetlands, the vertical hydraulic gradients that control groundwater outflows can be more heterogeneous due to local mounding under the wetlands as a result of changes in local sediment properties.

Although extensive water level monitoring of shallow and deep groundwater systems over multiple years conducted during this study is not practical for the majority of wetland delineations or evaluations, it demonstrates that even in drier wetland types such as wet prairie and sedge meadow that wetland hydrologic conditions do occur, but early in the growing season. Moreover, the documentation of wetland hydrology in these seasonal wetlands is also notable because the study period included periods of low annual precipitation and relatively low levels in the Great Lakes of the United States. Given the documented wetland hydrology under these conditions, wetland delineators should feel comfortable using professional judgment and the flexibility provided by regulatory manuals and guidance documents (such as those associated with USACE 1987) for wetland hydrology criteria determination in these seasonal wetlands. That is, even if the obvious indicators of wetland hydrology are not present during a site visit, the use of secondary indicators (e.g., FAC-neutral test, mapped soil survey data in USACE 1987) and the provisions allowed for "seasonal wetland" in USACE (1987) will help ensure that the wetland site condition that is documented by the soils and vegetation are reflected in the hydrology reported for that site. Accordingly, this ensures that when the plants and soils indicate it is a wetland, the wetland hydrology at the site is also properly characterized.

\section{Conclusions}

There are five primary findings from this work:

- Seasonal wetlands often appear dry for most of the growing season, but at the six sites investigated here, they met the United States regulatory wetland hydrol- ogy requirement of soil saturation for $5 \%$ of the growing season - a notable observation given the study period was characterized by below average precipitation and historically low levels in the Great Lake. The early growing season, when evapotranspiration is relatively small, is the period when this wetland hydrology criterion was met.

- Of the two types of wetlands characterized in this work, wet prairies had shorter periods of continuous soil saturation than sedge meadows. Given the similar leaf area densities between the two plant community types, it is likely that the difference results from differences in groundwater outflow rates from the wetland root zones.

- Unlike the groundwater dominated-wetlands of Hunt et al. (1999) where the root-zone residence times were characterized by a lognormal distribution, root-zone residence time data from the more precipitation dominated wetlands of this study did not fit a lognormal distribution. This suggests root-zone residence time approach may have to be generalized to include other distributions or summary statistics in drier wetlands.

- The 7- and 10-day high water level average statistics of Henszey et al. (2004) were a less labor-intensive approach to processing water-level data, but were not as effective at discriminating between the sedge meadow and wet prairie communities studied in this work. This type of high-water level approach may be superior to the root zone residence time for wetland delineation because it is more straightforward and easy to calculate. However, this statistic would have to be reported with the minimum water level during that period to ensure that water levels in the root zone were continuous during $5 \%$ of the growing season. Indeed, minimum water levels were appreciably affected by a substantial diurnal evapotranspiration signal that was superimposed on a less variable groundwater sink.

- When evaluating overall wetland hydrology, the sinks of water are as important as sources of water. Small differences in groundwater outflow rates can tip the balance and make a root zone slightly more or less wet, which in turn affects the resulting vegetation community. In addition, groundwater sinks can link a wetland to stresses in the regional groundwater system even if groundwater is not a dominant source of water to the wetland. In this work, declines in Great Lake levels lowered regional groundwater levels near the lake, which in turn were thought to enhance groundwater outflows from the wetland.

Acknowledgements This work was supported by a State of Wisconsin Coastal Management Program Grant, the Southeastern Wisconsin Regional Planning Commission, and US Geological Survey Cooperative Program. The authors thank two anonymous reviewers and the guest editor for their helpful comments. Special thanks are extended to J. Walker (USGS) for his generous contribution on the root zone residence time calculations and his review of the manuscript; to Dr. L. A. Leitner of the SEWRPC staff for assiting with the vegetation sampling and reviewing a draft of the manuscript; and to D. Roberts NRCS (emeritus) for the soil sampling and classifications. 


\section{References}

Bray JR, Curtis JT (1957) An ordination of the upland forest communities of southern Wisconsin. Ecol Monogr 27:325-349

Carter V (1986) An overview of the hydrologic concerns related to wetlands in the United States. Can J Botany 64:364-374

Cherkauer DS (2004) Quantifying ground-water recharge at multiple scales using PRMS and GIS. Ground Water 42(1):97-110

Chrzastowski MJ (2001) Geology of the Zion Beach-Ridge plain: field trip guidebook. Illnois State Geological Survey, Champaign, IL, $60 \mathrm{pp}$

Erwin KL (1989) Wetland evaluation for restoration and creation, In: Kusler JA, Kentula ME (eds) Wetland creation and restoration: the status of the science, vol 1. USEPA EPA 600/ 3-89/038b, USEPA, Washington, DC, pp 239-254

Good RE, Whigham DF, Simpson RL (1978) Freshwater wetlands. Academic, San Diego, CA

Greeson PE, Clark JR, Clark JE (1979) Wetland functions and values: the state of our understanding. American Water Resources Association, Middleburg, VA

Henszey RJ, Pfeiffer K, Keough JR (2004) Linking surface- and ground-water levels to riparian grassland species along the Platte River in Central Nebraska, USA. Wetlands 24(3):665-687

Hunt RJ (1996) Do created wetlands replace wetlands that are destroyed? USGS Fact Sheet FS-246-96, US Geological Survey, Reston, VA, 4 pp

Hunt RJ, Krabbenhoft DP, Anderson MP (1996) Groundwater inflow measurements in wetland systems. Water Resour Res 32(3):495-507

Hunt RJ, Krabbenhoft DP, Anderson MP (1997) Assessing hydrogeochemical heterogeneity in natural and constructed wetlands. Biogeochemistry 39:271-293

Hunt RJ, Bullen TD, Krabbenhoft DP, Kendall C (1998) Using stable isotopes of water and strontium to investigate the hydrology of a natural and a constructed wetland. Ground Water 36(3):434-443

Hunt RJ, Walker JF, Krabbenhoft DP (1999) Characterizing hydrology and the importance of ground-water discharge in natural and constructed wetlands. Wetlands 19(2):458-472

Ivanov KE (1981) Water movement in Wetlands. Academic, San Diego, CA

Link EG, Demo OR (1970) Soil survey of Kenosha and Racine Counties, Wisconsin. U.S. Department of Agriculture, Soil Conservation Service. US Government Printing Office, Washington, DC, $233 \mathrm{pp}$
MacBeth Division of Kollmorgen Instruments Corporation (2000) Munsell soil color chart, 2000 edn. MacBeth, Baltimore, MD

McCune B, Medford MJ (1995) PC-ORD multivariate analysis of ecological data, Version 3.0. MjM Software Design, Gleneden Beach, OR, USA

Mitsch WJ, Gosselink JG (2000) Wetlands, 3rd edn. Wiley, New York, $920 \mathrm{pp}$

National Cooperative Highway Research Program (1996) Guidelines for the development of wetland replacement areas. NCHRP Report 379 National Academy Press, Washington, DC

NRCS (National Water and Climate Center) (1995) Climate analysis for wetlands (WETS). WETS table documentation, National Water and Climate Center, Portland, OR. http://www.wcc.nrcs. usda.gov/climate/wets_doc.html. Cited 29 Jan 2007

NRCS (National Water and Climate Center) (2007) Climate Analysis for Wetlands from 1971-2000, WETS Station: Kenosha, WI4174, National Water and Climate Data Center, Portland, OR. Online source. ftp://ftp.wcc.nrcs.usda.gov/support/climate/wetlands/wi/ 55059.txt. Cited 29 Jan 2007

NRCS (Natural Resources Conservation Service) (2006) Field indicators of hydric soils in the United States: Guide for identifying and delineating hydric soils, Version 6.0, Natural Resources Conservation Service, Washington, DC

National Research Council (1995) Wetlands: characteristics and boundaries. National Academy Press, Washington, DC

Reed DM (2002) Environmental correlates of vegetation types in southeastern Wisconsin fens. PhD Thesis, University of Wisconsin, USA, $75 \mathrm{pp}$

Schneider AF (1983) Wisconsin stratigraphy and glacial sequence in southeastern Wisconsin. Geosci Wisconsin 7:59-85

SEWRPC (2004) Identifying and delineating problem wetlands in the Lake Michigan Basin using an integrated approach: a case study of two seasonal wetland types, Kenosha, Wisconsin, Memorandum Report No. 142, Southeastern Wisconsin Region Planning Commision, Waukesha, WI, $77 \mathrm{pp}$

USACE (1987) Corps of engineers wetlands delineation manual, Wetlands Research Program, Technical Report Y-87-1, US Army Corps of Engineers, $147 \mathrm{pp}$

US Department of Agriculture (1985) Hydric soils of the United States. USDA-SCS National Bulletin No. 430-5-9, USDA, Washington, DC

US Department of Interior (1970) National atlas of the United States. US Geological Survey, US Government Printing Office, Washington, DC, pp 110-111 